San Jose State University

SJSU ScholarWorks

Master's Theses

Master's Theses and Graduate Research

Spring 2019

\title{
The Moderating Effect of Self-Esteem on the Relationship Between Servant Leadership and Organizational Citizenship Behaviors
}

Whitney Kanavel

San Jose State University

Follow this and additional works at: https://scholarworks.sjsu.edu/etd_theses

\section{Recommended Citation}

Kanavel, Whitney, "The Moderating Effect of Self-Esteem on the Relationship Between Servant Leadership and Organizational Citizenship Behaviors" (2019). Master's Theses. 5003.

DOI: https://doi.org/10.31979/etd.uhr4-r889

https://scholarworks.sjsu.edu/etd_theses/5003

This Thesis is brought to you for free and open access by the Master's Theses and Graduate Research at SJSU ScholarWorks. It has been accepted for inclusion in Master's Theses by an authorized administrator of SJSU ScholarWorks. For more information, please contact scholarworks@sjsu.edu. 


\title{
THE MODERATING EFFECT OF SELF-ESTEEM ON THE RELATIONSHIP BETWEEN SERVANT LEADERSHIP AND ORGANIZATIONAL CITIZENSHIP BEHAVIORS
}

\author{
A Thesis \\ Presented to \\ The Faculty of the Department of Psychology \\ San José State University \\ In Partial Fulfillment \\ of the Requirement for the Degree \\ Master of Science
}

by

Whitney Kanavel

May 2019 
(C) 2019

Whitney Kanavel

ALL RIGHTS RESERVED 
The Designated Thesis Committee Approves the Thesis Titled

THE MODERATING EFFECT OF SELF-ESTEEM ON THE RELATIONSHIP BETWEEN SERVANT LEADERSHIP AND ORGANIZATIONAL CITIZENSHIP BEHAVIORS

\author{
by \\ Whitney Kanavel \\ APPROVED FOR THE DEPARTMENT OF PSYCHOLOGY \\ SAN JOSÉ STATE UNIVERSITY
}

May 2019
Dr. Megumi Hosoda
Department of Psychology
Dr. Howard Tokunaga
Department of Psychology
Courtney Good, MA
Bay Area Women's Sports Initiative




\title{
ABSTRACT \\ THE MODERATING EFFECT OF SELF-ESTEEM ON THE RELATIONSHIP BETWEEN SERVANT LEADERSHIP AND ORGANIZATIONAL CITIZENSHIP BEHAVIORS
}

\author{
By Whitney Kanavel
}

Previous research has shown that servant leadership is related to organizational citizenship behaviors. However, little attention has been paid to the possible moderators of this relationship. Therefore, the present study proposed that a personality characteristic (self-esteem) will moderate the relationship between servant leadership and organizational citizenship behaviors. It was hypothesized that the relationship between servant leadership and organizational citizenship behaviors would be stronger for employees with low self-esteem than for those with high self-esteem. Results of a selfreport survey from 204 employed individuals in various industries found that self-esteem moderated the relationship between servant leadership and organizational citizenship behaviors. Consistent with the hypothesis, the relationship between servant leadership and OCB was stronger when individuals had low self-esteem than when individuals had high self-esteem. This result suggests that personality characteristics may be an important variable to consider when examining the relationship between servant leadership and organizational citizenship behavior in future studies. 


\section{ACKNOWLEDGEMENTS}

First and foremost, I would like to thank my thesis committee for providing their expertise and guidance throughout this process. Specifically, I would like to highlight Dr. Megumi Hosoda for your endless support and encouragement. I truly cannot thank you enough for your time, energy, and commitment to my success during the entirety of this research and writing process. I will forever be grateful for you and your dedication to my growth. I would also like to thank Dr. Howard Tokunaga for preparing me for the thesis process and for your feedback and support. I had my first of many wonderful "Aha!" moments in your courses. Thank you for helping me see that I am more than qualified to make a name for myself in this field of work. Courtney Good, I am so grateful for your encouragement to apply for this program and for your support throughout the entirety of it. You were there from the application process and cheered me on through every milestone. I am very fortunate to have a great leader, mentor, and friend like you.

Mom and Dad, I would not be here without you. Thank you supporting my dreams, no matter where they take me. Thank you both for keeping me on track in the pursuit of my goals. I will forever appreciate all of the times you listened to my worries and doubts, continuing to reassure me that I can accomplish anything. To Andy, you are the reason I chase my dreams. Your support and love is unconditional and I will forever be grateful for you. You continue to give me the strength to accomplish anything and everything I set my mind to. I hope I have made you proud. 
To my siblings, grandparents, aunts and uncles, and the rest of my extended family: you are my biggest cheerleaders and I could not do any of this without you. You constantly picked my head up when I was feeling down. Your encouragement and support was everything to me during this process! Finally, a special thanks to my program cohort. Having a group of likeminded people working through the many difficult times we had together and always ready to support one another through everything was crucial to my achievements in this program. 


\section{TABLE OF CONTENTS}

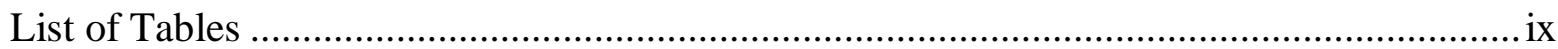

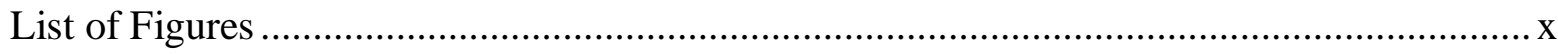

Introduction ....1.

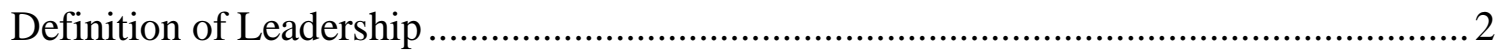

A Brief History of Leadership Theories ..................................................................... 3

Trait approach to leadership............................................................................. 3

Behavioral approach to leadership ....................................................................... 4

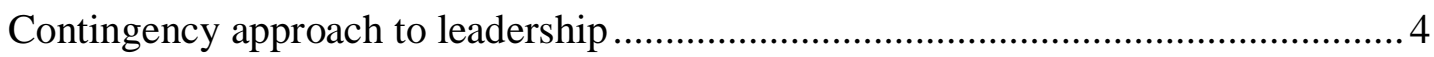

New leadership approach to leadership ................................................................

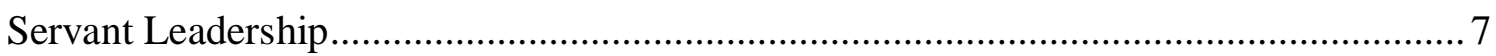

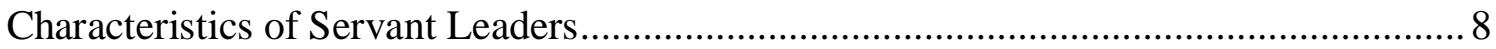

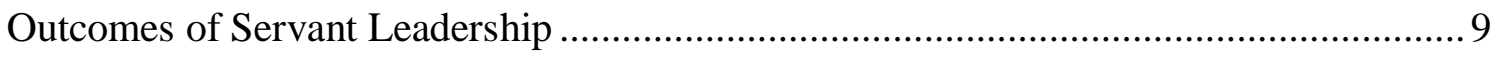

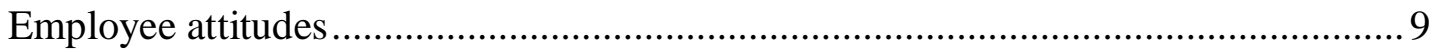

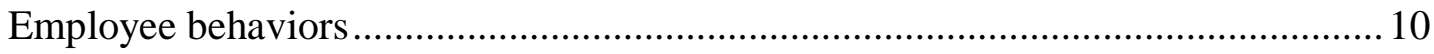

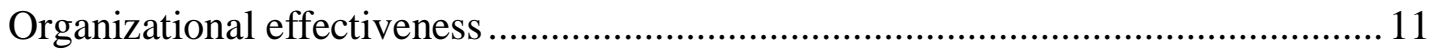

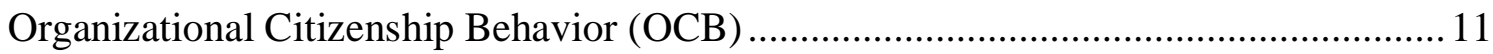

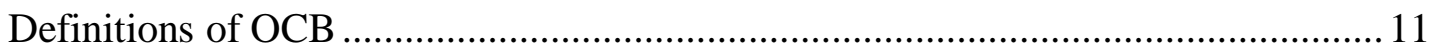

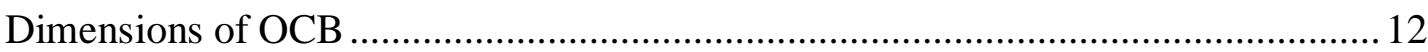

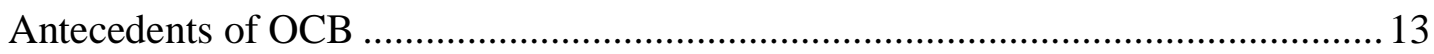

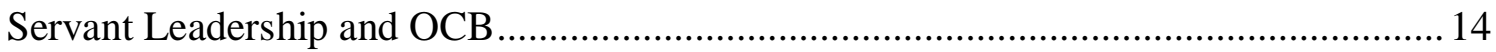

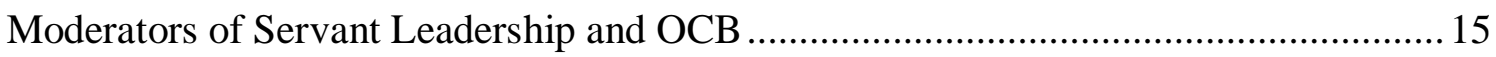

Self-Esteem as a Moderator of Servant Leadership and OCB ........................................ 18

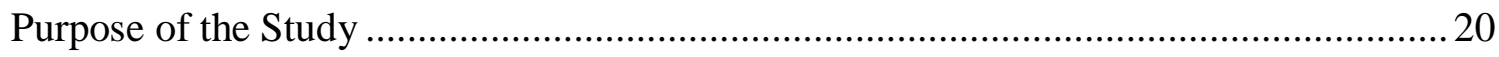

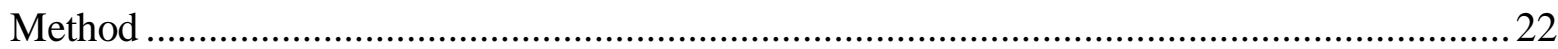

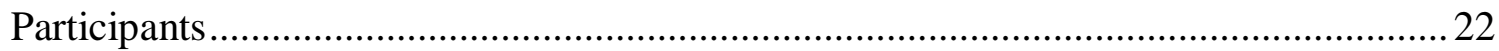

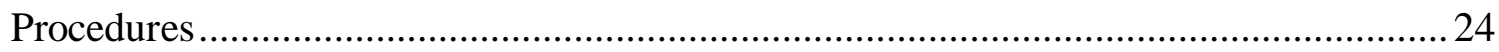

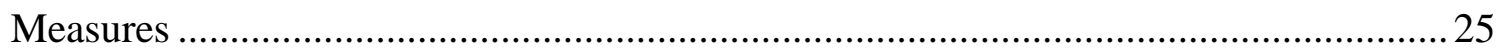

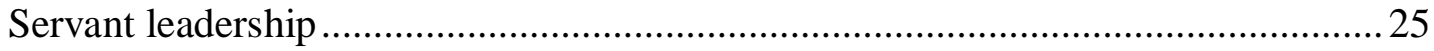

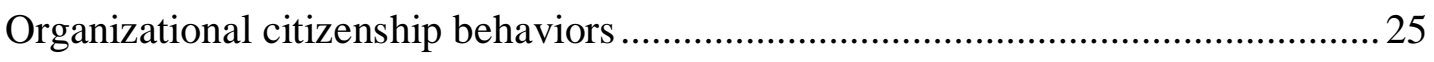

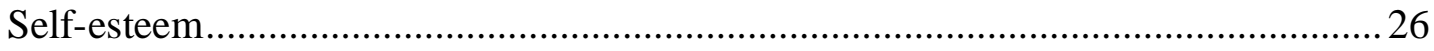

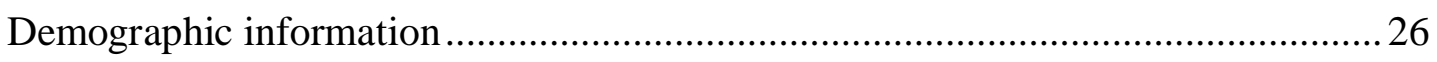




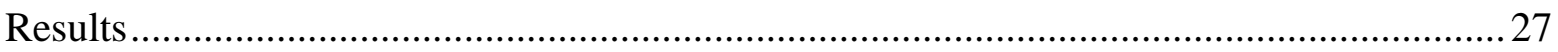

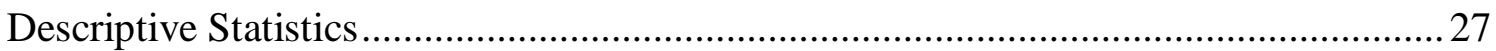

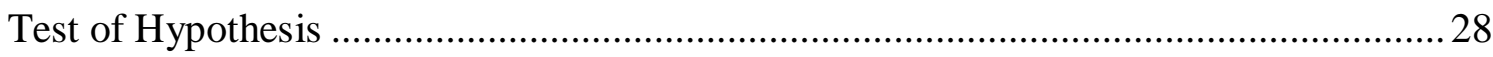

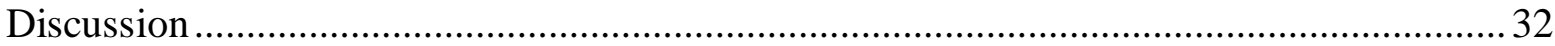

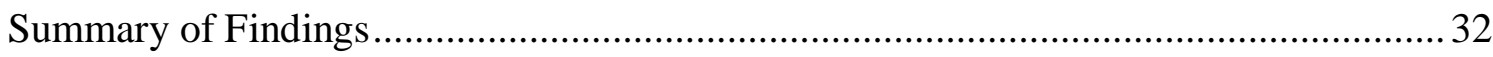

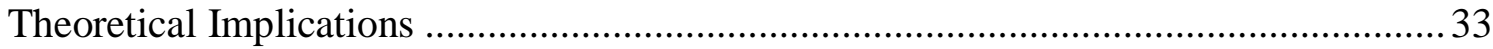

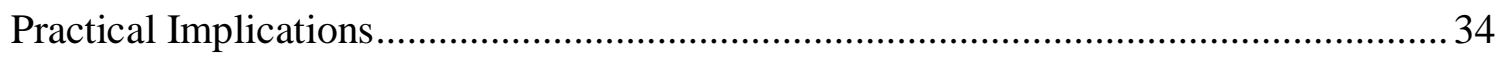

Strengths, Limitations, and Future Directions ....................................................... 35

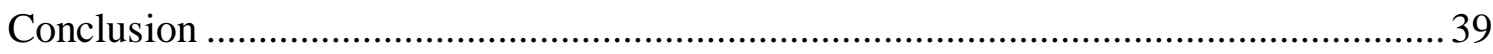

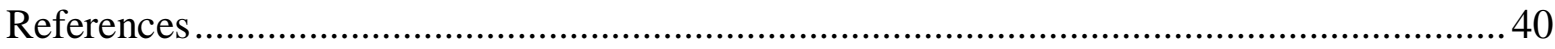

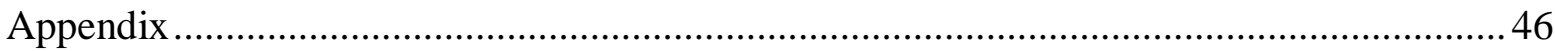

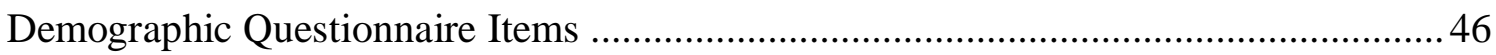

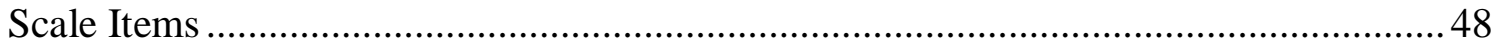




\section{LIST OF TABLES}

Table 1. Demographic Characteristics of Survey Respondents

Table 2. Descriptive Statistics, Pearson Correlations, and Cronbach's Alpha Among Servant Leadership, OCB, and Self-Esteem

Table 3. Hierarchical Multiple Regression Analysis for Servant Leadership, SelfEsteem, and OCB. 


\section{LIST OF FIGURES}

Figure 1. Moderating effect of self-esteem on the relationship between servant leadership and OCB 


\section{Introduction}

Over the past few decades, leadership has evolved into a heavily researched topic within the behavioral sciences. As the corporate world becomes more complex and competitive, organizations must learn how to adapt to these challenges in order to be successful. The success of an organization is often dependent on the effectiveness of its leaders (Barrow, 1977). With an ongoing emphasis on finding competent and effective leaders in the workplace, numerous styles of leadership have been developed and researched over time.

Despite the large amount of research available on leadership, it seems as though organizations are still struggling to find leaders who have the ability to successfully motivate their employees to accomplish organizational goals and complete tasks. Klenke (2003) suggests that leaders' inability to motivate their employees has to do with problems with the style of leadership. Klenke (2003) adds to this notion by suggesting that productivity in the workplace has recently declined due to the implementation of poor strategic management decisions that have resulted in negative consequences such as outsourcing, corporate mergers, acquisitions, and downsizing. The problems many organizations face may stem from poor decisions being made by leaders in the workplace which might indicate problems with the leadership approaches being used.

One leadership style that may help motivate employees is servant leadership. Greenleaf (1997) describes a servant leader as an individual who wants to serve - more specifically, to serve first and lead second. He goes on to say that servant leaders have a natural desire to serve others, a feeling that must be authentic. Available but limited 
research on servant leadership shows that this concept is related to positive outcomes such as employee satisfaction, voluntary extra-role behaviors also known as organizational citizenship behaviors (OCB), and reduced turnover (Stone, Russell, \& Patterson, 2004; Walumbwa, Hartnell, \& Oke, 2010; Wayne, Shore, \& Liden, 1997). However, knowledge about servant leadership continues to be limited. For example, research has yet to successfully clarify psychological mechanisms or boundary conditions regarding the influence servant leaders may have on followers and any associated outcomes of that influence (Avolio, Walumbwa, \& Weber, 2009; Panaccio, Henderson, Liden, Wayne, \& Cao, 2015). Therefore, to help close this gap in research, this study aims to examine the relationship between servant leadership and OCB, while examining self-esteem as a moderator of the relationship.

The following sections provide popular definitions of leadership, a brief history of leadership theories, the history of servant leadership, the characteristics of servant leadership, the outcomes of servant leadership, OCB, the relationship between servant leadership and OCB, self-esteem as a moderator, and finally the hypothesis that is tested in the present study.

\section{Definition of Leadership}

Leadership is a heavily examined topic in the social sciences (Day \& Antonakis, 2012), mainly because it is a universal activity evident in human kind and in animal species (Bass, 2007). There are many definitions of leadership; Fielder (1971) noted that "there are almost as many definitions of leadership as there are leadership theories" (p. 1). For example, Yammarino (2013) defined leadership as multi-level interaction where 
both leader and follower share a purpose and strive to jointly accomplish tasks.

Similarly, Lord and Dinh (2014) defined leadership as a "social process that involves iterative exchange processes among two (or more) individuals" (p. 161). Osland, Kolb, and Rubin (2008) defined leaders as individuals who establish a direction for a group, gain group members' commitment, and motivate group members to achieve goals to move in that direction. Despite the absence of universal agreement on the definition of leadership, Bryman (1992) argued that most definitions of leadership emphasize three main elements: group, influence, and goal.

\section{A Brief History of Leadership Theories}

Trait approach to leadership. The scientific study of leadership began at the turn of the $20^{\text {th }}$ century (Day \& Antonakis, 2012). This approach is one of the earliest theories of leadership and focuses on the profile of an "ideal" leader. This approach assumes that leaders have characteristics that set them apart from non-leaders and attempts to identify those distinguishing characteristics. Leaders who possess these key traits are believed to be effective across different times and situations. The trait approach focuses on identifying the personality, ability, and physical characteristics of leaders. However, Stodgill's (1948) and Mann's (1959) reviews found no connections between these characteristics and leader effectiveness. Effective leaders did not differ from noneffective leaders in clear and consistent ways. After these reviews, interest in the trait approach faded and shifted to the behavioral approach. However, a more recent metaanalysis (Judge, Bono, Ilies, \& Gehart, 2002) found that several personality traits (e.g. emotional stability, extraversion, openness to experience) were related to the emergence 
of leaders and leader effectiveness, indicating that certain traits were important in predicting leader emergence and effectiveness.

Behavioral approach to leadership. As defined by Mosley (1998), the behavioral approach to leadership "incorporates the view that leaders are responsible for shaping an environment that enables followers to achieve specific tasks" (p. 42). This approach emphasizes the idea that leaders can shape their behaviors in order to influence their followers (Mosley, 1998). Unlike the trait approach, which focuses on what leaders are like, the behavioral approach focuses on what leaders do. Within this approach, there are two types of leadership styles: task-oriented behaviors and relationship-oriented behaviors (Stogdill, 1950). Task-oriented behaviors focus on setting goals, accomplishing tasks, and achieving organizational goals, whereas relationship-oriented behaviors focus on establishing mutual trust, respect, and rapport between the leader and follower (Stogdill, 1950). Results of a meta-analysis (Judge, Piccolo, \& Ilies, 2004) found that relationship-oriented behaviors were more strongly related to outcomes such as follower satisfaction with a leader, follower job satisfaction, and leader effectiveness than task-oriented behaviors.

Contingency approach to leadership. Fielder (1967) was credited with the contingency approach to leadership movement as he argued that researchers needed to consider the situations leaders were in when they studied leadership. One well-known and well-developed theory under this approach is leader-member exchange (LMX) (Graen \& Uhl-Bien, 1995). LMX theory has been established as a prominent framework for understanding how leaders meet organizational goals through the relationships they 
have with their followers. The main premise of LMX theory is that leaders develop different dyadic relations with different subordinates (Graen, 1976). In-group members are subordinates who share high-quality relationships with their leader, whereas outgroup members are subordinates who have low-quality relationships with their leader. High-quality relationships are based on social exchange, trust, and respect, whereas lowquality relationships are based on agreed-upon transactions or monetary exchanges (Seo, Nahrgang, Carter, \& Hom, 2018). Results of a meta-analysis (Gerstner \& Day, 1997) found that in-group members were more likely to receive higher performance ratings from their leader, were more satisfied with their jobs, more committed to their organizations, and less likely to develop an intention to quit their jobs than out-group members.

New leadership approach to leadership. The new approach to leadership appeared around the 1980s (Day \& Antonakis, 2012). Many researchers have studied leadership mainly as a style that is predominately transactional in nature, but more contemporary theories of leadership turn the focus towards leading with a sense of purpose and away from completing a transaction (Day \& Antonakis, 2012). Two examples of the new leadership approach to leadership are transformational leadership and authentic leadership.

Bass (1985) introduced transformational leadership theory. According to this theory, the purpose of the transformational leader is to motivate followers to do more than what is expected of them. Transformational leadership occurs when leaders broaden and elevate the interests of their employees, generate awareness and acceptance of the 
purpose and mission of the group, and encourage employees to look beyond their own self-interest for the good of the group (Bass, 1985). Transformational leaders transform their followers by motivating them to go beyond their own self-interests for the good of the organization, raising their commitment to the organization's vision, appealing to their higher ideals and moral values (e.g., justice, peace, equality), activating higher-order needs in followers, and articulating a vision of a better world while demonstrating how to achieve it (Bass, 1985). Results of a meta-analysis (Judge \& Piccolo, 2004) found that transformational leadership was positively related to followers' motivation and satisfaction with their jobs and leaders.

Authentic leadership is a style of leadership that focuses on positive behaviors that are self-regulated; these leaders have a high level of self-awareness (Avolio, Gardner, Walumbwa, Luthans, \& May, 2004). Authentic leaders are aware of who they are as a person as well as what they value, and use this self-awareness as a guide for their leadership. Authentic leaders rely heavily on their morals as a compass or guide for their leadership (Avolio et al., 2004). One study found that authentic leaders could help facilitate followers' practicing and utilizing core value behavior. In addition, when employees practiced the organization's core values along with their own, they were more likely to be committed to work, engaged with their work, and willing to work (Oh \& Daeyeon, 2018).

Although the leadership styles discussed above (trait approach, behavioral approach, LMX, transformational leadership, and authentic leadership) are unique, all five of them have one thing in common: they trend as top-down approaches. Typically, top-down 
approaches start with upper management leaders and then trickle down toward lower level employees. An example of this would be a teacher leading his or her students or a manager leading his or her direct-report employees. Despite the commonality amongst these five leadership styles, some researchers have chosen to examine the less-popular bottom-up approach to leadership. For example, Yang, Ming, Ma, and Huo (2017) found that the use of a bottom-up strategy led to an increase in work engagement. These results are similar to those of Ouweneel, Le Blanc, and Schaufeli (2013) who found that leaders who emotionally invested in their employees were likely to see an increase in their employee's commitment and work engagement. A lesser-known style of leadership, servant leadership, places its emphasis on serving others from the bottom-up, making this approach stand out from top-down styles of leadership (Greenleaf, 1977).

\section{Servant Leadership}

Servant leadership occurs when a leader chooses to put others first, focusing on his or her own needs second. Servant leadership is distinguishable from the leadership styles mentioned above due to the fact that care is taken to ensure that employees' highest priority needs are met and served above and before anything else (Greenleaf, 2002). Savage-Austin and Honeycutt (2011) believe that the philosophy of servant leadership provides a new way of tackling leadership in the workplace, eliminating the traditional top-down approach in which many leaders utilize.

The most widely accepted definition of servant leadership is provided by Greenleaf (1997), who described it as a way of life rather than just a management technique. This way of life begins with "the natural feeling that one wants to serve, to serve first" 
(Greenleaf, 1997, p. 7). In other words, he believed that in order to be a servant leader, one must have a natural desire to serve first and lead second. Additionally, Sendjaya and Sarros (2002) found that servant leaders were primarily motivated to serve others with a secondary goal of developing their own selves. Consistent with these definitions, Dutta and Khatri (2017) see a servant leader as someone who naturally focuses his or her attention on people rather than on processes or outcomes in an organization.

\section{Characteristics of Servant Leaders}

Van Dierendonck (2011) established six characteristics of servant leaders: empowering and developing employees, humility and modesty, authenticity, acceptance of others, providing direction, and stewardship. Empowering and developing others refers to fostering a positive, self-confident attitude among followers and giving them a sense of personal power. Humility and modesty refers to putting one's own talents and accomplishments in a proper perspective. Authenticity focuses on expressing one's true self. Acceptance of others refers to having the ability to understand and experience others' feelings. Providing direction refers to providing a proper degree of accountability and creating new approaches to old problems. Finally, stewardship is defined as taking responsibility for the larger group or organization and focusing on service rather than on control.

Greenleaf (1977) suggested that servant leaders motivate their followers by prioritizing the fulfillment of their followers' needs above satisfying their own needs. Similarly, both Rude (2003) and Nwogu (2004) describe servant leaders as those who stray from the use of power, influence, and self-serving behaviors, and instead step into a 
position where they empower, encourage, and enable their followers. The theme is clear in that servant leaders place an emphasis on satisfying the needs of their followers through empowerment and creating a safe and trusting environment. Wong, Davey, and Church (2007) suggest that servant leaders place an emphasis on creating a trusting, genuine, and positive work environment where followers feel safe.

Because servant leadership is a relatively new concept, research on servant leadership is still very limited. Much of the current research on servant leadership consists of measurement tools for servant leadership and theoretical frameworks with hopes of researchers exploring this construct further (Parris \& Peachy, 2013). The relative lack of research creates a gap in knowledge on servant leadership. However, despite the small amount of literature available on servant leadership, the research conducted on this style of leadership has grown tremendously within the last decade, indicating that more researchers are interested in understanding how this style of leadership may lead to a more productive and effective workplace.

\section{Outcomes of Servant Leadership}

Employee attitudes. The impact that servant leaders have on their followers is positive for the individual. For example, Jones (2011) found that servant leadership in an organization led to increased employee satisfaction. Wayne, Shore, and Liden (1997) showed that organizations that chose to sustain a culture of servant leadership had more satisfied employees, who were in turn more committed to the organization's values and continued to maintain higher levels of overall performance. Similarly, Grisaffe and Jaramillo (2007) found that servant leadership played a role in enhancing the well-being 
of followers; followers exhibited greater pride for their organization, were more likely to believe that their jobs supported personal growth and development, were more likely to feel as though they were being challenged, and reported feeling a higher sense of achievement. Additionally, Chiniara and Bentein (2016) found that the influence that servant leadership had on followers led to an increase in the follower's satisfaction of their three basic psychological needs. In other words, when followers had been influenced by a servant leader, they were more likely to feel as though their basic psychological needs for autonomy, competence, and relatedness were being met.

Employee behaviors. Servant leadership has been shown to be related to desirable employee behaviors. For example, Walumbwa et al. (2010) found a positive relationship between servant leadership and OCB. According to this study, servant leaders went beyond thinking of themselves and instead placed their focus on expressing genuine care and concern for their employees. Because of the genuine behavior expressed by the servant leader, followers engaged in acts of OCB toward their leader. This was seen as a form of exchange to support and sustain the positive social environment in response to the leader's behavior.

In addition to OCB, a study by Hunter et al. (2013) found that servant leadership was related to a decrease in follower turnover intentions and a decrease in disengagement. This same study found that servant leadership at the store-level led to an increase in follower helping behavior. Additionally, Jaramillo, Grisaffe, Chonko, and Roberts (2009), and Black (2010) found that servant leadership led to a decrease in turnover intention because a positive work environment was established, thus leading employees 
to feel more committed to the organization. Another benefit of servant leadership was reported by Yang, Liu, and Gu (2017) who found that servant leadership increased creativity at both the individual and team levels.

Organizational effectiveness. Servant leadership is not only beneficial to the individual, but also to the organization. For example, Jones (2011) found that servant leadership resulted in "greater organizational productivity as well as increased fiscal strength as evidenced by decreased turnover, increased job satisfaction, and increased revenues” (p. 95). Furthermore, Liden, Panaccio, Meuser, Hu, and Wayne (2014) suggested that an organization that relied on the servant leadership approach was more likely to see an increase in positive outcomes through the results of an increase in in-role performance, creativity, and reduced turnover.

In sum, it is evident from existing research that servant leadership has many positive outcomes for individuals and organizations. Of all of the positive outcomes that servant leadership provides, OCB has become the most popular construct to be explored by researchers. Though there seems to be an obvious relationship between servant leadership and OCB, there are still gaps in understanding this relationship in depth.

\section{Organizational Citizenship Behavior (OCB)}

Definitions of OCB. Organ (1988) defined OCB as "individual behavior that is discretionary, not directly or explicitly recognized by the formal reward system, and that in the aggregate promotes the effective functioning of the organization" (p. 4). In simpler terms, OCB can be thought of as extra-role behaviors that an employee engages in voluntarily. However, given that "discretionary" can differ depending on people as well 
as situations, Organ (1997) later redefined OCB as "performance that supports the social and psychological environment in which task performance takes place” (p. 95). Some examples of OCBs are helping colleagues, attending work meetings or team bonding activities that are not required, and volunteering to take on more work activities that are not part of an employee's standard job responsibilities.

Dimensions of OCB. Many dimensions of OCB have been identified. For example, Smith, Organ, and Near (1983) came up with two dimensions of OCB: altruism and generalized compliance. Altruism refers to behaviors that go beyond what is being asked of the individual in order to benefit or serve others. An example of altruism would be helping someone who has been absent from the office remain on top of his or her workload. Generalized compliance refers to behaviors that benefit the organization but that are not formally rewarded (Smith et al., 1983). An example of generalized compliance would be upholding company rules.

A few years later, Organ (1988) expanded the taxonomy of OCB to five dimensions: altruism, conscientiousness, sportsmanship, civic virtue, and courtesy. The definition of altruism remained the same in this expanded understanding of OCB. Conscientiousness is the narrower form of generalized compliance. An example of someone who is conscientious would be an employee who chooses to be punctual every day. Sportsmanship refers to a behavior during which individuals endure uncomfortable or complicated matters without complaining and staying positive in unfavorable circumstances; an example would be not complaining about trivial matters. Civic virtue refers to participating actively in an organization's political life. An example of civic 
virtue would be keeping up with and reading work-relevant mail. Lastly, courtesy refers to the act of "checking in" with colleagues regarding any decisions or commitments that are relevant to them; an example would be consulting with coworkers before making a decision.

Antecedents of OCB. Podsakoff, MacKenzie, Paine, and Bachrach (2000) conducted a meta-analysis on the antecedents of OCB. They examined three broad categories of antecedents: individual characteristics (e.g., personality traits, job attitudes), task characteristics (e.g., task feedback, intrinsically satisfying task), and leader behaviors (e.g., LMX, transformational leadership). Results showed that individual characteristics such as job satisfaction, organizational commitment, and the personality trait of conscientiousness were positively related to various forms of OCBs. For task characteristics, results showed that task feedback was positively related to OCBs. Furthermore, leader behaviors such as transformational leadership, LMX, and the contingent rewards of transactional leadership were positively related to OCBs. Based on their meta-analysis, Podsakoff, Podsakoff, MacKenzie, Maynes, and Spoelma (2015) concluded that leaders played a key role in determining OCB among their employees and that attitudinal variables (e.g., job satisfaction, organizational commitment) were also important determinants of OCB. Similarly, Organ, Podsakoff, and Mackenzie (2006) found that OCBs resulted from employees with positive job attitudes (e.g. job satisfaction), positive affect, employees who considered themselves to be in a supportive organizational climate, and employees whose leaders were encouraging. 


\section{Servant Leadership and OCB}

Given that servant leaders foster a positive work environment through serving, supporting, and encouraging their subordinates, it is very likely that servant leadership could be an antecedent of OCB. Social exchange theory (Moorman \& Bryne, 2005) can be used to explain the relationship between servant leadership and OCB. Social exchange theory indicates that social relationships are based on the exchange of benefits between parties, that individuals enter and remain in the exchange relationships as long as the benefits outweigh the costs, and that they behave based on the norm of reciprocity (Moorman \& Bryne, 2005). Servant leaders put their subordinates first, help them grow and succeed, establish trust, and show care and concern for them. Consequently, subordinates become motivated to reciprocate the leaders' actions and behaviors by going above and beyond what is required of them and engaging in OCB (Walumbwa et al., 2010).

Research shows that servant leadership is positively related to OCB (Newman, Schwarz, Cooper, \& Sendjaya, 2017). For example, Ehrhart (2004) and Hunter et al. (2013) both found that servant leadership inspired followers to mirror their leaders' actions, which resulted in followers expressing helping behaviors such as OCB.

Similarly, Walumbwa et al. (2010) found that servant leadership was related to several individual and group level mediators (i.e., self-efficacy, commitment to supervisor, procedural justice climate and service climate), which in turn predicted followers' engagement in OCB. The results of this study revealed that procedural justice climate and positive service climate partially mediated the relationship between servant leadership 
and OCB. Procedural justice climate is a distinct group-level cognition regarding how a specific group as a whole is treated. Service climate refers to employees shared perceptions about an organization's practices and policies specifically referring to rewards, support, and customer service. Walumbwa et al. (2010) suggested that the positive relationship between servant leadership and procedural justice climate might be representative of the leaders' moral responsibility to their followers. Alternatively, the positive relationship between servant leaders and service climate may be indicative of the leaders' focus on the organization's stakeholders. Based on these findings, Walumbwa et al. (2010) suggest that future research consider including other climates, such as safety climate to further explain the servant leadership and OCB relationship. Safety climate refers to the perception about an organization's policies regarding safety procedures and practices. Despite the short list of research available on this topic, the results of the studies mentioned above lead me to believe that servant leadership is related to OCB.

\section{Moderators of Servant Leadership and OCB}

Although the relationship between servant leadership and OCB has been found in past studies, researchers (e.g., Panaccio et al., 2015) have suggested that future scholars examine any mediating and/or boundary conditions that may strengthen or weaken the relationship between servant leadership and outcomes. Currently, research is void of studies that have examined boundary conditions of the relationship between servant leadership and OCB. Despite this, one study has suggested that individual personality characteristics may be influential in the relationship between servant leadership and outcomes. 
Specifically, Panaccio et al. (2015) examined extraversion, collectivism, and proactive personality as boundary conditions of the relationship between servant leadership and psychological contract fulfillment. Psychological contract is defined as “individual beliefs, shaped by the organization, regarding terms of an exchange agreement between individuals and their organization', (Rousseau 1995, p. 9). Psychological contract fulfillment is referred to as individuals' perception that the exchange agreement has been met by the employer (Pannaccio et al., 2015). Extraversion is referred to as a trait "containing an agency component, which involves ambition, dominance and reward sensitivity, and an affiliation component, comprised of sociability, enjoying and valuing relationships with others" (Panaccio et al., 2015, p. 662). Collectivism is a belief by individuals who view themselves as being interdependent with those around them, and proactive personality refers to the tendency in which an individual takes initiative to improve the current situation or create a new situation (Panaccio et al., 2015).

Drawing from substitutes-for-leadership theory (Kerr \& Jamier, 1978), which proposes that the influence of leadership is contingent on individual characteristics of subordinates, task characteristics, and organizational characteristics, Panaccio et al. (2015) proposed that individual differences in personality "predispose followers to have access to rewards and resources from sources other than their leader, thus making them less dependent upon their leaders for psychological contract fulfillment, constituting boundary conditions which influence the strength of the relationship between servant leadership behaviors and follower outcomes" (Panaccio et al., 2015, p. 669). 
Thus, the researchers argued that extroverted individuals, collectivistic individuals, and proactive individuals have access to rewards and resources that contribute to psychological contract fulfillment not only from their servant leaders but also from sources other than their servant leaders; thus, these individuals become less dependent on their leaders to obtain resources and rewards that fulfill their psychological contracts. Extroverted individuals rely less on their leaders because they are sociable, assertive, and ambitious; they have an extended network of people in the organization at their disposal. Panaccio et al. (2015) suggested that extroverts had an easier time networking with others and gaining social capital; a benefit in which servant leaders typically provide, thus experiencing psychological contract fulfillment can be done without the help of a servant leader. In contrast, introverted individuals were more likely to lack these social and networking skills and depend on servant leaders for the fulfillment of their psychological contract.

Likewise, collectivistic individuals value cooperation, self-sacrifice, and harmony, and build stronger relationships with others, eliminating the need for a servant leader to help fulfill their psychological contracts. Furthermore, collectivistic individuals typically have more informal contacts with their co-workers, are more likely to work in teams, and tend to receive more support than individualists, and hence they have better developed relationships with others. Because collectivists surround themselves with support, the need for a leader to fulfill their psychological contract is somewhat diminished. Conversely, individualists value autonomy, competition, and freedom and do not 
typically pay close attention to developing strong relationships with others, thus, they are more likely to rely on the help of a servant leader to fulfill their psychological contracts.

Panaccio et al. (2015) found that the relationship between servant leadership and psychological contract fulfillment was stronger and more positive when extraversion was low and when collectivism was low. These results indicate that those low on extraversion and collectivism benefited more from servant leaders for the fulfillment of psychological contract than those high on extraversion and collectivism, respectively. Simply put, when influenced by a servant leader, introverts and individualists were more likely to experience perceived psychological contract fulfillment in their employment relationship. Results did not show support for proactive personality.

\section{Self-Esteem as a Moderator of Servant Leadership and OCB}

Despite the fact that Yukl (2006) questioned whether practices of servant leadership are effective across situations and characteristics, research that has examined the moderating role of personality characteristics on the relationship between servant leadership and outcomes has been scarce. Panaccio et al's. (2015) findings lead me to believe that personality characteristics might play a role in other follower outcomes of servant leadership, such as OCB. In order to contribute to literature, I am interested in exploring the moderating effect of the personality characteristic, self-esteem, on the relationship between servant leadership and OCB, knowing that personality characteristics might be important boundary conditions to examine.

Self-esteem is defined as "a global feeling of self-worth or adequacy as a person, or generalized feelings of self-acceptance, goodness, and self-respect” (Lyubomirsky, 
Tkach, \& DiMatteo, 2006, p. 366). In other words, self-esteem refers to the degree to which people feel good about themselves and are confident with whom they are. For example, individuals with high self-esteem are happy with who they are and consider themselves worthy of respect, whereas individuals with low self-esteem typically do not regard themselves as worthy of positive outcomes and have a lower sense of self-respect.

I contend that the positive relationship between servant leadership and OCB will be stronger among those low in self-esteem than among those high in self-esteem. The reasoning behind this assumption is based on social exchange theory and reciprocity norm (Gouldner, 1960). As mentioned earlier, social exchange theory refers to weighing the costs and rewards in relationships. Reciprocity norm refers to reciprocating behaviors (i.e. positive behaviors are reciprocated with positive behaviors, negative behaviors are reciprocated with negative behaviors). For example, servant leaders put their subordinates first, help them grow and succeed, establish trust, and show care and concern for them. Followers then reciprocate servant leaders' actions and behaviors by going above and beyond their duties.

However, servant leadership is likely to have a stronger positive effect on followers who are low in self-esteem because an individual who reports having low self-esteem may need the boost in encouragement and empowerment that a servant leader is sure to provide. Knowing that servant leaders attempt to foster a positive, self-confident attitude among their followers leads me to believe that followers with low self-esteem will be lifted up and encouraged by their servant leader; this empowerment will then motivate 
followers to engage in reciprocal behaviors that aim to help others and their organization, specifically engaging in extra-role behaviors such as OCB.

Conversely, individuals who report having high self-esteem may already feel a sense of self-acceptance and empowerment (Tan, Krishnan, \& Lee, 2017) and the need for a servant leader motivating them to go above and beyond somewhat diminishes. Because their sense of self is already positive, the reinforcement of servant leadership may not have as strong of an effect on them resulting in feeling little need to reciprocate behaviors to their leader or organization because they are less dependent on needing their leader to encourage them to do more. As a result, I predict that followers low in self-esteem will be more likely to engage in extra-role behaviors than followers high in self-esteem because of the encouragement and motivation provided by the servant leader. Therefore, I hypothesize the following:

Hypothesis: Self-esteem will moderate the positive relationship between servant leadership and OCB such that the relationship between servant leadership and OCB will be stronger for those individuals low in self-esteem than for those individuals high in self-esteem.

\section{Purpose of the Study}

Servant leadership may prove to be the missing puzzle piece for successfully motivating employees to accomplish organizational goals and complete tasks. Researchers have found that servant leadership is indeed related to many positive individual and organizational outcomes, such as an employee engaging in extra-role behaviors. However, existing research has failed to examine boundary conditions of such 
relationships. Because of this relatively large gap in literature, this study aims to examine the possible moderating effect that self-esteem may have on the relationship between servant leadership and OCB.

Overall, I hope to gain a better understanding of how the relationship between servant leadership and extra-role behaviors will change as a function of the self-esteem of followers. My goals for this study are to further investigate the relationship between servant leadership and OCB and contribute to closing the gap in literature regarding boundary conditions. 


\section{Method}

\section{Participants}

Data were collected through an online survey. More than 1,000 individuals were invited to participate in the study; 229 individuals responded, resulting in a response rate of $30 \%$. Participants who did not meet the criteria (currently employed, 18 years or older) or had a substantial amount of missing data were removed from further analyses. Thus, the final sample consisted of 204 participants.

The demographic information of participants is presented in Table 1. When looking at age, $61.7 \%$ of the sample were between the age of 18 and $34,15.2 \%$ between the ages of 35 and 44, 13.7\% between age 45 and 54, 9.3\% were 55 years or older. The majority of the sample was female $(76.5 \%)$, followed by male $(23.0 \%)$, and transgender $(0.5 \%)$. The majority of participants also identified themselves as White (69.6\%), followed by $15.2 \%$ of the sample identifying as Hispanic, Latino, or Spanish, and 9.8\% identifying as Asian. The remaining $5.5 \%$ of the sample identified as other races. 
Table 1

Demographic Characteristics of Survey Respondents $(N=204)$.

\begin{tabular}{|c|c|c|c|}
\hline & Variable & $\mathrm{n}$ & $\%$ \\
\hline \multirow[t]{5}{*}{$\overline{\text { Age }}$} & $18-24$ & 59 & $28.9 \%$ \\
\hline & $25-34$ & 67 & $32.8 \%$ \\
\hline & $35-44$ & 31 & $15.2 \%$ \\
\hline & $45-54$ & 28 & $13.7 \%$ \\
\hline & 55 or older & 19 & $9.3 \%$ \\
\hline \multirow[t]{3}{*}{ Gender } & Female & 156 & $76.5 \%$ \\
\hline & Male & 47 & $23.0 \%$ \\
\hline & Transgender & 1 & $0.5 \%$ \\
\hline \multirow[t]{6}{*}{ Race } & Asian & 20 & $9.8 \%$ \\
\hline & American Indian / Alaska Native & 1 & $0.5 \%$ \\
\hline & Black / African American & 1 & $0.5 \%$ \\
\hline & Hispanic, Latino, or Spanish Origin & 31 & $15.2 \%$ \\
\hline & White & 142 & $69.6 \%$ \\
\hline & Other & 9 & $4.5 \%$ \\
\hline \multirow[t]{6}{*}{ Organization } & For profit & 92 & $45.1 \%$ \\
\hline & Non-profit & 13 & $6.4 \%$ \\
\hline & Government & 10 & $4.9 \%$ \\
\hline & Health care & 20 & $9.8 \%$ \\
\hline & Education & 42 & $20.6 \%$ \\
\hline & Other & 27 & $13.2 \%$ \\
\hline \multirow{2}{*}{$\begin{array}{l}\text { Employment } \\
\text { Status }\end{array}$} & Part-time & 33 & $16.2 \%$ \\
\hline & Full-time & 171 & $83.8 \%$ \\
\hline \multirow[t]{5}{*}{ Length of Employment } & Less than 6 months & 27 & $13.2 \%$ \\
\hline & 6-12 months & 46 & $22.5 \%$ \\
\hline & 1-3 years & 54 & $26.5 \%$ \\
\hline & 4-6 years & 21 & $10.3 \%$ \\
\hline & 7 years or more & 56 & $27.5 \%$ \\
\hline
\end{tabular}


The majority of participants worked in for-profit organizations $(45.1 \%)$ with the next largest group of individuals working in education (20.6\%). The remaining participants work in a variety of other organization types. Regarding employment status, $83.8 \%$ of the participants were employed full-time and the remaining $16.2 \%$ were part-time employees. Organizational tenure was evenly distributed; $27.5 \%$ of participants were employed at their current company for more than 7 years, followed by $26.5 \%$ who were employed for 1 to 3 years, $22.5 \%$ who were employed for 6-12 months, $13.2 \%$ who had only been at their company for 6 months, and $10.3 \%$ of participants who were employed for 4-6 years.

\section{Procedure}

Data were collected online via Qualtrics, an online survey platform. Employees from various industries and backgrounds received an invitation to participate in the survey through two social media platforms: Facebook and LinkedIn. Following the original post inviting individuals to participate, approximately nine individuals shared the survey with their networks, allowing for data collection to reach beyond my personal network of connections.

The invitation contained a brief message detailing the purpose of the study, a short description of the nature of the study, and a link to the survey. Participants who clicked the link were directed to a consent form. The consent form stated the purpose of the study, who to contact with any questions, information about the risks and benefits of the study, and the anonymous and voluntary nature of the survey. When participants clicked the button "I consent, continue with survey," participants indicated their willingness to continue with completing the survey. Participants who selected the option "I do not 
consent, exit survey" were taken directly to the end of the survey and thanked for their participation. An unsigned consent notice was deemed appropriate due to the anonymous nature of the project and minimal risk involved. Participants had the ability to start and stop the survey freely and the option to end the survey at any time. After the survey was completed, they were thanked for their participation and Qualtrics automatically exited them from the survey. All responses were logged in Qualtrics.

\section{Measures}

Servant leadership. Servant leadership was measured by Ehrhart's (2004) 14-item Servant Leadership questionnaire which assesses individuals' beliefs about their supervisor. The items were measured on a 5-point Likert scale, ranging from 1 (Strongly Disagree) to 5 (Strongly Agree). Sample items included "My supervisor creates a sense of community among employees" and "My supervisor emphasizes the importance of giving back to the community." The responses were combined and averaged to create a composite score for this variable. Higher scores indicated that participants believed their supervisor exhibited more servant leadership behaviors. Cronbach's alpha for this variable was .93 , indicating high reliability.

Organizational citizenship behavior. OCB was measured using Lee and Allen's (2002) 16-item OCB Scale which assessed individuals' level of engagement in helping behaviors in the workplace. All 16 items were measured on a 5-point Likert scale ranging from 1 (Strongly Disagree) to 5 (Strongly Agree). Sample items include "I help others who have been absent" and "I go out of my way to make newer employees feel welcome in the group" and "I express loyalty to my organization." Higher scores 
indicated that employees engaged in helping behaviors towards their peers and their organization. Responses to the 16 items were combined and averaged to create a composite score for this variable. Cronbach's alpha was .85 , indicating high reliability.

Self-esteem. The Rosenberg Self-Esteem Scale (RSES) was used to measure the selfesteem of participants using 10 questions (Rosenberg, 1965). This scale measured participant's feelings about themselves on a 5-point Likert scale ranging from 1 (Strongly Disagree) to 5 (Strongly Agree). Sample items included "I take a positive attitude toward myself" and "I certainly feel useless at times." A higher score indicated higher selfesteem. Responses to the 10 items were combined and averaged to create a composite score for this variable. Cronbach's alpha was .88, indicating high reliability.

Demographic information. In addition to the three variables being measured, there were six questions relating to one's personal background and/or experiences. These six items measuring demographic information were age, gender, race, organization, employment status, and length of employment.

Once data were collected, they were analyzed using the Statistical Package for the Social Sciences (SPSS Version 25) program. 


\section{Results}

\section{Descriptive Statistics}

Table 2 displays the descriptive statistics of the measured variables and correlations among them. On average, participants rated their supervisors somewhat high in servant leadership $(M=3.67, S D=.74)$. Participants also reported that they displayed relatively high levels of OCB $(M=4.03, S D=.43)$ and that participants had high self-esteem $(M=$ $4.03, S D=.61)$. Overall, the participants in the current study felt as though their supervisor or manager displayed high servant leadership behaviors, meaning that supervisors likely empowered, encouraged, and instilled trust in their subordinates. Participants also reported that they displayed behaviors that went beyond what was expected of them in their role. The sample, overall, had a high sense of self-esteem, indicating that they felt confident in who they were and respected themselves as a person.

Table 2

Descriptive Statistics, Pearson Correlations, and Cronbach's Alpha Among Servant Leadership, $O C B$, and Self-Esteem $(N=204)$

\begin{tabular}{|c|c|c|c|c|c|c|c|}
\hline Variable & $M$ & $S D$ & 1 & & 2 & & 3 \\
\hline 1. Servant Leadership & 3.67 & .74 & $(.93)$ & & & & \\
\hline 2. $\mathrm{OCB}$ & 4.03 & .43 & .49 & $* * *$ & $(.85)$ & & \\
\hline 3. Self-Esteem & 4.03 & .61 & .25 & $* * *$ & .30 & $* * *$ & $(.88)$ \\
\hline
\end{tabular}

Note: Reliability coefficients (Cronbach's alpha) are in parentheses along the diagonal. $* \mathrm{p}<.05 * * \mathrm{p}<.01 * * \mathrm{p}<.001$ 
Results of the Pearson correlations showed that the three variables were significantly and positively related to one another. There was a strong and positive relationship between servant leadership and OCB, $r(202)=.49, p<.001$, such that the more participants experienced having a servant leader as their supervisor, the more likely they were to engage in behaviors that went beyond their daily responsibilities. A significant and moderately strong positive relationship was found between OCB and self-esteem, $r(202)=.30, p<.001$. This finding indicated that those engaging in more extra-role behaviors were also likely to have higher self-esteem or vice versa. Lastly, there was a significant and moderately strong positive relationship between servant leadership and self-esteem, $r(202)=.25, p<.001$, such that subordinates with a supervisor who exhibited more servant leader behaviors were related to subordinates having a higher selfesteem.

\section{Test of Hypothesis}

A hierarchical multiple regression correlation (MRC) analysis was used to test the hypothesis. For this MRC analysis, three steps were used. Servant leadership was entered into the first step. The moderator variable of self-esteem was entered in the second step. Lastly, the cross-product of servant leadership and self-esteem was entered in the third step to test for the moderating effect. Results of the analysis are shown in Table 3. 
Table 3

Hierarchical Multiple Regression Analysis for Servant Leadership, Self-Esteem, and $O C B(N=204)$

\begin{tabular}{lllll} 
& Predictor & $r$ & $\mathrm{R}^{2}$ & $\Delta \mathrm{R}^{2}$ \\
\hline Step 1 & & & $.24 * * *$ & $.24 * * *$ \\
Step 2 & Servant Leadership & $.49 * * *$ & & \\
& Self-Esteem & $.30 * * *$ & $.28 * * *$ & $.04 * *$ \\
Step 3 & & $.29 * * *$ & $.01 *$ \\
& $\begin{array}{l}\text { Servant Leadership } \mathrm{x} \\
\text { Self-Esteem }\end{array}$ & $.53 * *$ & & \\
$* \mathrm{p}<.05 * * \mathrm{p}<.01 * * * \mathrm{p}<.001$ & & &
\end{tabular}

Results from the first step of the analysis showed that servant leadership accounted for $24 \%$ of the variance in OCB, $R^{2}=.24, R^{2}$ adj $=.24, F(1,202)=63.93, p<.001$. This means that servant leadership significantly contributed to the prediction of participants' engagement in OCB. In the second step, self-esteem accounted for an additional $4 \%$ of variance in OCB beyond the effect of servant leadership, $\Delta R^{2}=.04, \Delta F(1,201)=9.70 p$ $<.01$. This indicates that self-esteem predicted participants' engagement in OCB above and beyond the effect of servant leadership. Results of the third step showed that the incremental effect of the interaction of servant leadership and self-esteem was significant, accounting for an additional variance of $1 \%$ in $\mathrm{OCB}$, above and beyond the effects of servant leadership and self-esteem, $\Delta R^{2}=.01, F(1,200)=4.41, p<.05$. This suggests that self-esteem moderated the relationship between servant leadership and OCB.

In order to illustrate the nature of the significant moderating effect, self-esteem was dichotomized using a median split to create "low" and "high" conditions. A simple 
regression analysis was conducted for each condition of self-esteem. Results are shown in Figure 1. A simple slope analysis showed that servant leadership was positively related to OCB among those with low self-esteem $(\beta=.26, t=5.25, p<.001)$. Similarly, the regression analysis showed that there was also a significant and positive relationship between servant leadership and OCB among those with high self-esteem $(\beta=.28, t=$ $5.53, p<.001)$.

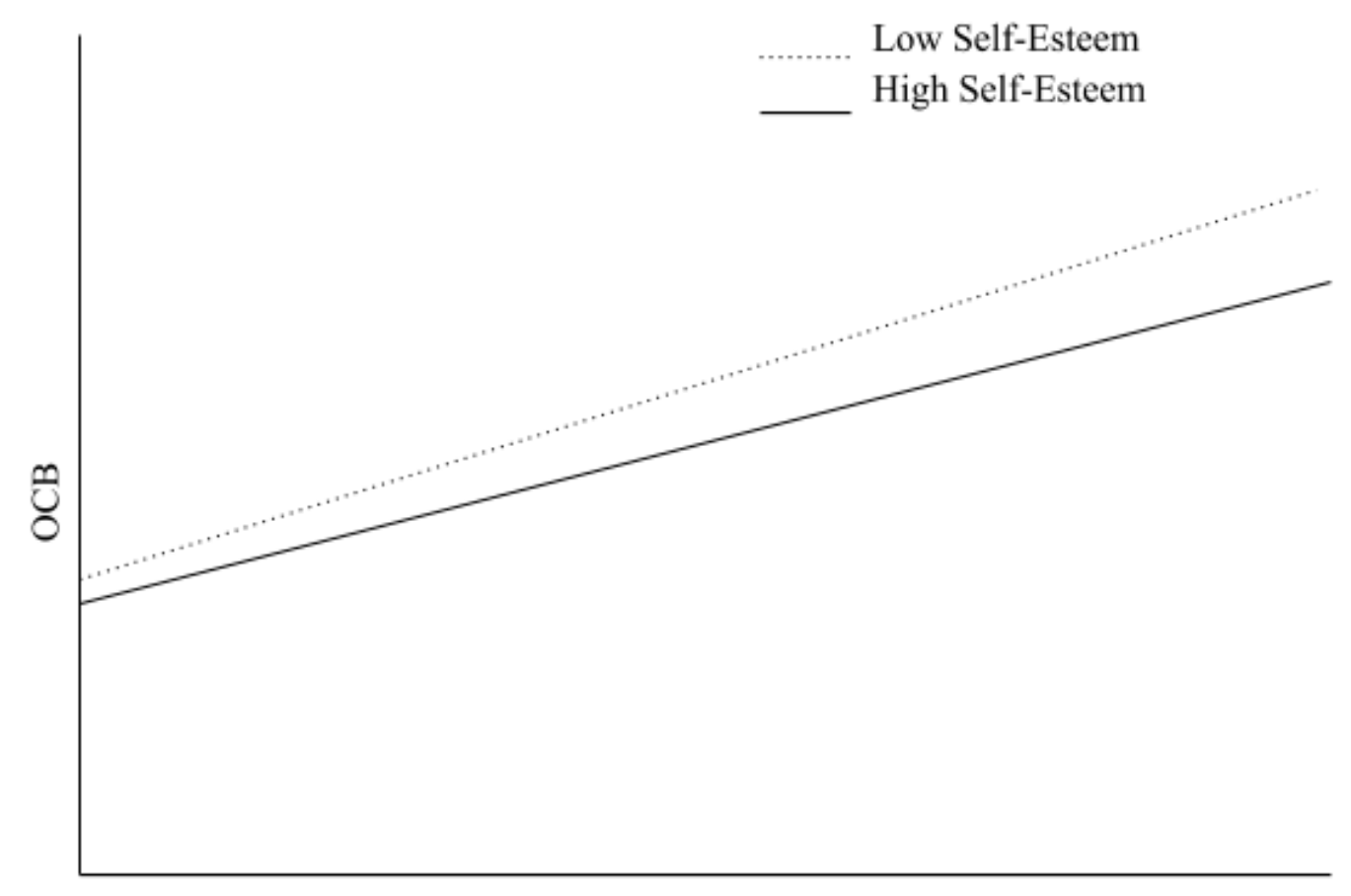

Servant Leadership

Figure 1. Moderating effect of self-esteem on the relationship between servant leadership and OCB.

These results indicate that individuals whose supervisors displayed more servant leader behaviors were more likely to engage in OCB. This is true for both low selfesteem and high self-esteem individuals. However, the relationship between servant 
leadership and OCB was slightly stronger for individuals with low self-esteem compared to individuals with high self-esteem. These results indicate that individuals with low selfesteem were somewhat more likely than those with high self-esteem to go above and beyond in the workplace, specifically when their supervisor showed strong servant leadership tendencies. These results show support for the hypothesis. 


\section{Discussion}

Organizations continue to struggle with finding competent leaders who can motivate their employees to accomplish organizational goals and tasks. Because of this challenge, the current study examined servant leadership, a relatively new style of leadership, as a tool that may help motivate employees to go above and beyond their daily responsibilities. Although the relationship between servant leadership and OCB has been well established (Ehrhart, 2004; Hunter et al., 2013; Newman, Schwarz, Cooper, \& Sendjaya, 2017; Walumbwa et al., 2010) research has yet to identify boundary conditions for this relationship (Panaccio et al., 2015). Thus, this study proposed self-esteem as a boundary condition for the relationship between servant leadership and OCB. This study aimed to understand if the relationship between servant leadership and OCB would change as a function of followers' self-esteem.

\section{Summary of Findings}

The hypothesis for the current study stated that self-esteem would moderate the relationship between servant leadership and OCB such that the relationship between servant leadership and OCB would be stronger for individuals low in self-esteem than for individuals high in self-esteem. Results of the hierarchical regression analysis showed that servant leadership predicted OCB positively. Furthermore, self-esteem was also found to predict OCB above and beyond the effect of servant leadership. These results indicate that individuals who had servant leaders and those with high self-esteem were more likely to engage in OCB. However, results also showed that self-esteem moderated the relationship between servant leadership and OCB. Further analyses showed that there 
was a significant and positive relationship between servant leadership and OCB for both low self-esteem participants and high self-esteem participants. However, the relationship between servant leadership and OCB was stronger when self-esteem was low than when self-esteem was high. More specifically, individuals who considered themselves having lower self-esteem were more likely to engage in OCB when servant leadership was high than individuals who considered themselves having high self-esteem. These results are consistent with the study's research hypothesis and suggest that the support and guidance from one's servant leader empower those low in self-esteem to go above and beyond the call of duty and engage in more OCB than those high in self-esteem.

\section{Theoretical Implications}

Consistent with literature, the results of the present study showed a significant relationship between servant leadership and OCB. Consistent with social exchange theory, servant leaders encourage, empower, and provide support to their subordinates before all else, thus the subordinates reciprocate such leaders' actions and behaviors with extra-role behaviors that help both individuals and organizations.

Panaccio et al. (2015) called for more research on mediating and boundary conditions for the relationship between servant leadership and outcomes (e.g., OCB) suggesting that personality characteristics be studied as boundary conditions. Taking on that advice, this study hypothesized that self-esteem would act as a moderator of the relationship between servant leadership and OCB. Results showed support for the hypothesis. This study contributes to the existing literature because it identified one boundary condition for the relationship between servant leadership and OCB. It showed that the relationship between 
servant leadership and OCB is not direct, but it changes as a function of subordinates' levels of self-esteem and demonstrates that personality characteristics, such as selfesteem, do play a moderating role.

\section{Practical Implications}

The practical implications of the results of this study are geared towards organizations. Because a common problem organizations face has to do with leadership styles, it is important that organizations fill their management positions with competent leaders. Given that servant leadership was significantly and positively related to OCB, organizations should consider leadership styles when selecting employees to fill management positions. Part of Greenleaf's (1977) explanation of servant leadership highlights the idea that servant leaders have a natural desire to serve others. That being said, servant leadership is not something that can be taught or trained. Rather, organizations should focus on selecting individuals for management positions who exhibit empowering, encouraging, authentic, and servant-like behaviors. By selecting these types of individuals to fill management positions, organizations are likely to see increased OCB from employees. If these behaviors are not easily distinguishable by one individual, then perhaps organizations should implement 360-degree feedback regarding leadership style and behavior on the individual they are considering for the position. Collecting information from a group of people that are directly impacted (i.e. employees, coworkers, managers) by the individual in question would be necessary for 360-degree feedback. 
Next, given that self-esteem was significantly related to OCB, organizations should focus on fostering a positive work environment in order to boost employees' feelings of empowerment and support. This can be done in several ways, but as a suggestion, organizations could implement personal development workshops that help individuals increase their overall confidence and self-respect. This could involve bringing in a subject matter expert on personal development, particularly in the area of self-esteem. Organizations can also create a workplace environment that is positive, encouraging, and empowering by instilling these behaviors into the company's culture. These behaviors would need to be modeled by the leaders of the organization and trickle down in order to set the standard of expected behaviors. By creating an environment that promotes and supports high self-esteem, an organization will likely see an increase in their employees' engagement in OCB.

\section{Strengths, Limitations, and Future Directions}

The current study has several strengths. To begin, this study was the first to examine personality characteristics (i.e., self-esteem) as a boundary condition for the relationship between servant leadership and OCB. This is a strength because it contributes to the current literature on servant leadership and what is known about this style of leadership. Second, this study had a large sample size. Because of the large sample size, this study was able to find the significant moderating effect of self-esteem on the relationship between servant leadership and OCB and again contribute to the literature on servant leadership. The large sample size also allowed my findings to be more generalizable, have a better test of the hypothesis, and allowed me to have more faith in my findings. 
Third, the sample was diverse in its demographics, allowing me to study individuals from different types of organizations, ages, and race/ethnicity. This is a strength because the level of self-esteem might have been well represented, revealing that different backgrounds and experiences might affect one's self-esteem. This is important particularly for future research in that demographics might be a factor to consider in the relationship between servant leadership and OCB.

As with any other study, the current study is not without limitations. First, the use of self-report surveys may not be the most accurate form of collecting information about the variables measured. For example, people may report false information about themselves, there may be outside factors that influence the way a participant responds to the survey (i.e. a recent negative experience that contributed to low self-esteem, noise level or distraction level while completing the survey, time available to complete the survey, previous knowledge of the scales being used, and consistency motif, or responding to questions in a similar manner) (Podsakoff \& Organ, 1986). Furthermore, when participants complete a self-report survey, they may answer based on what they believe is the "correct" or socially acceptable way to answer questions about themselves, thus distorting data (Maccoby \& Maccoby, 1954, as cited in Fisher, 1993).

Although researchers cannot control for events that affect an individual's' personal life or well-being, there are ways to help minimize some of these factors. For example, I suggest hosting the data collection in person. This would be useful because the survey administrator can explain to those taking the survey that participants will not be judged by the answers provided and that there is no way to trace any information back to them. 
Although the consent form states that the nature of the survey is anonymous, I believe that people may feel more confident in being honest when hearing the anonymity explained to them in person. This also allows participants to ask questions. An in-person survey will also allow the survey administrator to control for noise and distractions as well as timing. Another suggestion for minimizing such problems would be to have the supervisors' rate their subordinates' OCB, rather than subordinates' self-reporting their own in engagement in OCBs. This is likely to minimize inflated responses to individuals' engagement in such behaviors.

Next, although the sample size was large, there is a relative lack of variability in responses. For example, means for the three variables (servant leadership, OCB, and self-esteem) were relatively high and standard deviations were small, thus lowering the ability to differentiate participants from one another. The majority of participants felt as though their supervisor or manager displayed servant leadership behaviors, the majority of participants reported engaging in behaviors that were beyond what was expected of them in their role, and the majority of participants believed to have a high sense of selfesteem, meaning they felt confident in who they were and they respected themselves. It is important to be able to compare participants with one another to distinguish between individuals with low versus high self-esteem or those with and without a servant leader. Given that the slope of the regression lines for both low and high self-esteem were similar, it is possible that a wider variability in responses might have revealed a clearer pattern of the interaction between servant leadership and self-esteem on OCB. 
Though the current study found a significant moderating effect, the effect was small. The significant moderating effect of self-esteem on the relationship between servant leadership and OCB might be due to a large sample size. This assumption was drawn because the regression lines for both low self-esteem and high self-esteem were almost parallel. Although the present study shows support for the moderating effect of selfesteem, future research should be conducted to see if the results could be replicated.

Based on the moderating role of self-esteem, there may be other personality traits that moderate the relationship between servant leadership and various outcomes. Thus, future research should focus on examining different personality characteristics (i.e. Big Five personality traits) as boundary conditions for the relationship between servant leadership and OCB as well as other outcomes. One personality trait I would suggest examining as a moderator would be conscientiousness. Individuals who are high in conscientiousness are responsible, dependable, persistent, and achievement oriented (Wang \& Bowling, 2016). Therefore, the need for a servant leader to influence their engagement in OCB is unlikely. On the contrary, individuals who are low in conscientiousness are typically anti-social, less motivated to be successful, and more laid back (Wang \& Bowling, 2016). This type of behavior might be easily influenced by the encouragement and support provided by that of a servant leader and thus individuals may become motivated to go above and beyond their daily responsibilities.

Finally, future research should also be directed towards not only identifying other moderator variables for the relationship between servant leadership and OCB, but researchers should consider identifying moderators of the relationship between servant 
leadership and other outcomes (e.g., counterproductive behaviors). There is still so much to be discovered about this style of leadership, therefore such research will be instrumental in contributing to today's literature on the topic of servant leadership.

\section{Conclusion}

The current study identified one leadership style that may help motivate employees to go above and beyond their daily responsibilities: servant leadership. However, knowledge about servant leadership continues to be limited. Research is still lacking answers to possible mechanisms or boundary conditions regarding the influence servant leaders may have on followers and any associated outcomes of that influence (Avolio et al., Panaccio et al., 2015). This study contributed to minimizing that gap by finding selfesteem as a moderator of the relationship between servant leadership and OCB. With the proposed hypothesis returning significant results, it is important that future scholars continue to examine personality characteristics as boundary conditions in order to better understand the relationship between servant leadership and OCB. 


\section{References}

Avolio, B. J., Gardner, W. L., Walumbwa, F. O., Luthans, F., \& May, D. R. (2004). Unlocking the mask: A look at the process by which authentic leadership impact follower attitudes and behaviors. The Leadership Quarterly, 15, 801-823.

Avolio, B. J., Walumbwa, F. O., \& Weber, T. J. (2009). Leadership: Current theories, research, and future directions. Annual Review of Psychology, 60, 421-449.

Barrow, J. (1977). The variables of leadership: A review and conceptual framework. Academy of Management Review, 2, 231-251.

Bass, B. (1985). Leadership: Good, better, best. Organizational Dynamics, 13, 26-40.

Bass, B. (2007). Concepts of leadership. Leadership: Understanding the dynamics of power and influence in organizations (2nd ed.), (pp. 3-22). Notre Dame, IN:

University of Notre Dame Press.

Black, G. L. (2010). Correlational analysis of servant leadership and school climate. Journal of Catholic Education, 13, 437-466. doi: 10.15365/joce.1304032013

Bryman, A. (1992). Charisma and leadership in organizations. London: Sage Publications.

Chiniara, M. \& Bentein, K. (2016). Linking servant leadership to individual performance: Differentiating the mediating role of autonomy, competence and relatedness need satisfaction. The Leadership Quarterly, 27, 124-141.

Day, D. V. \& Antonakis, J. (2012) Leadership: Past, present, and future. The Nature of Leadership, 2, 3-25.

Dutta, S. \& Khatri, P. (2017). Servant leadership and positive organizational behaviour: the road ahead to reduce employees' turnover intentions. On the Horizon, 25, 60-82.

Ehrhart, M. G. (2004). Leadership and procedural justice climate as antecedents of unitlevel organizational citizenship behavior. Personnel Psychology, 57, 61-94. doi: $10.1111 / \mathrm{j} .1744-6570.2004$

Fielder, F. E. (1967). The effect of inter-group competition on group member adjustment. Personnel Psychology, 20, 33-44.

Fielder, F. E. (1971). Validation and extension of the contingency model of leadership effectiveness: A review of empirical findings. Psychological Bulletin, 76, 128-148. 
Fisher, R. J. (1993). Social desirability bias and the validity of indirect questioning. Journal of Consumer Research, 20, 303-315.

Gerstner, C. R. \& Day, D. V. (1997). Meta-analytic review of leader-member exchange theory: Correlates and construct issues. Journal of Applied Psychology, 82, 827844.

Gouldner, A. (1960). The norm of reciprocity: A preliminary statement. American Sociological Review, 25, 161-178. doi:10.2307/2092623

Graen, G. B. (1976). Role making processes within complex organizations. Handbook of Industrial and Organizational Psychology, 4, 1201-1245.

Graen, G. B. \& Uhl-Bien, M. (1995). Relationship-based approach to leadership: Development of leader-member exchange (LMX) theory of leadership over 25 years: Applying a multi-level multi-domain perspective. The Leadership Quarterly, 6, 219-247.

Greenleaf, R. K. (1977). Servant leadership: A journey into the nature and legitimate power and greatness. New York: Paulist Press.

Greenleaf, R.K. (1997). The servant as leader. Leadership: Understanding the dynamics of power and influence in organizations, (pp. 429-438). Notre Dame, IN: University of Notre Dame Press.

Greenleaf, R. K. (2002). Servant-leadership: A journey into the nature of legitimate power and greatness. Mahwah, NJ: Paulist Press.

Grisaffe, D. B. \& Jaramillo, F. (2007). Toward higher levels of ethics: Preliminary evidence of positive outcomes. Journal of Personal Selling \& Sales Management, $27,355-371$.

Hunter, E. M., Neubert, M. J., Perry, S., Witt, L. A., Penney, L. M., \& Weinberger, E. (2013). Servant leaders inspire servant followers: Antecedents and outcomes for employees and the organization. The Leadership Quarterly, 24, 316-331.

Jaramillo, F., Grisaffe, D. B., Chonko, L. B., \& Roberts, J. A. (2009). Examining the impact of servant leadership on salesperson's turnover intention. Journal of Personal Selling \& Sales Management, 29, 351-365.

Jones, D. (2011). Does servant leadership lead to greater customer focus and employee satisfaction. Business Studies Journal, 4, 22-33. 
Judge, T. A. \& Piccolo, R. F. (2004) Transformational and transactional leadership: A meta-analytic test of their relative validity. Journal of Applied Psychology, 89, 755-768.

Judge, T. A., Bono, J. E., Ilies, R., \& Gehart, M. W. (2002). Personality and leadership: A qualitative and quantitative review. Journal of Applied Psychology, 87, 765780 .

Judge, T. A., Piccolo, R. F., \& Ilies, R. (2004) The forgotten ones? The validity of consideration and initiating structure in leadership research. Journal of Applied Psychology, 89, 36-51.

Kerr, S., \& Jermier, J. M. (1978). Substitutes for leadership: Their meaning and measurement. Organizational Behavior \& Human Performance, 22, 375403. doi: 10.1016/0030-5073(78)90023-5

Klenke, K. (2003). The "S" factor in leadership education, practice, and research. Journal of Education for Business, 79, 56-61.

Lee, K. \& Allen, N. J. (2002) Organizational citizenship behavior and workplace deviance: The role of affect and cognitions. Journal of Applied Psychology, 87, 131-142. doi: 10.1037/0021-9010.87.1.131

Liden, R., Panaccio, A., Meuser, J., Hu, J., \& Wayne, S. (2014). Servant leadership: antecedents, processes, and outcomes. The Oxford Handbook of Leadership and Organizations, 357-379.

Lord, R. G. \& Dinh, J. E. (2014). What have we learned that is critical in understanding leadership perceptions and leader-performance relations? Industrial and Organizational Psychology: Perspectives on Science and Practice, 7, 158-177.

Lyubomirsky, S., Tkach, C., \& DiMatteo, M. R. (2006). What are the differences between happiness and self-esteem? Social Indicators Research, 78, 363-404.

Maccoby, E. E., \& Maccoby, N. (1954). The interview: A tool of social science. Handbook of Social Psychology, 1, 449-487.

Mann, R. D. (1959). A review of the relationships between personality and performance in small groups. Psychological Bulletin, 56, 241-270.

Moorman, R. H. \& Byrne, Z. S. (2005). How does organizational justice affect organizational citizenship behavior? In J. Greenberg \& J. A. Colquitt (Eds.), Handbook of organizational justice, (pp. 355-380). Mahwah, NJ: Erlbuam. 
Mosley, A. L. (1998). A behavioral approach to leadership: Implications for diversity in today's organizations. Journal of Leadership Studies, 5, 38-50.

Newman, A., Schwarz, G., Cooper, B., \& Sendjaya, S. (2017). How servant leadership influences organizational citizenship behavior: The roles of LMX, empowerment, and proactive personality. Journal of Business Ethics, 145, 49-62.

Nwogu, O. G. (2004). Servant leadership model: The role of follower self-esteem, emotional intelligence, and attributions on organizational effectiveness. Proceedings of the Servant Leadership Research Roundtable, Regent University.

Oh, J. \& Daeyeon, L. D. (2018). Authentic leadership and work engagement: The mediating effect of practicing core values. Leadership \& Organizational Development Journal, 39, 276-290.

Organ, D. W. (1988). Organizational citizenship behavior: The good soldier syndrome. Lexington, MA, England: Lexington Books/D.C. Health and Company.

Organ, D. W. (1997). Organizational citizenship behavior: It's construct clean-up time. Human Performance, 10, 85-97.

Organ, D. W., Podsakoff, P.M., \& Mackenzie, S.B. (2006). Organizational citizenship behavior: Its nature, antecedents, and consequences. USA: Sage Publications, Inc.

Osland, J. S., Kolb, D. A., \& Rubin, I. M. (2008). Organizational behavior: An experiential approach. London, UK: Pearson Education.

Ouweneel, E., Le Blanc, P. M., \& Schaufeli, W. B. (2013). Do-it-yourself: An online positive psychology intervention to promote positive emotions, self-efficacy, and engagement at work. The Career Development International, 18, 173-195.

Panaccio, A., Henderson, D. J., Liden, R. C., Wayne, S. J., \& Cao, X. (2015). Toward an understanding of when and why servant leadership accounts for employee extrarole behaviors. Journal of Business and Psychology, 30, 657-675.

Parris, D. L., \& Peachey, J. W. (2013). A systematic literature review of servant leadership theory in organizational contexts. Journal of Business Ethics, 113, 377393.

Podsakoff, N. P., Podsakoff, P. M. MacKenzie, S. B., Maynes, T. D., Spoelma, T. M. (2015). Consequences of unit-level organizational citizenship behaviors: A review and recommendations for future research. Journal of Organizational Behavior, 35 , 87-119. 
Podsakoff, N. P, Whiting, S. W., \& Podsakoff, P. M., \& Blume, B. (2009). Individualand organizational-level consequences of organizational citizenship behaviors: A meta-analysis. Journal of Applied Psychology, 94, 122-141.

Podsakoff, P. M., MacKenzie, S. B., Paine, J., \& Bachrach, D. G. (2000). Organizational citizenship behaviors: A critical review of the theoretical and empirical literature and suggestions for future research. Journal of Management, 26, 513-563.

Podsakoff, P. M., \& Organ, D. W. (1986). Self-reports in organizational research: Problems and prospects. Journal of Management, 12, 531-544. doi: $10.1177 / 014920638601200408$

Rosenberg, M. (1965). Society and the adolescent self-image. Princeton, NJ: Princeton University Press.

Rousseau, D. M. (1995). Psychological contracts in organizations: Understanding written and unwritten agreements. Thousand Oaks, CA, US: Sage Publications, Inc.

Rude, W. (2003). Paradoxical leadership: The impact of servant-leadership on burnout of staff. Proceedings of the Servant Leadership Research Roundtable, Regent University, 181-193.

Savage-Austin, A. R., \& Honeycutt, A. (2011). Servant leadership: A phenomenological study of practices, experiences, organizational effectiveness, and barriers. Journal of Business \& Economics Research), 9, 49-55.

Sendjaya, S., \& Sarros, J. (2002). Servant leadership: Its origin, development, and application in organizations. Journal of Leadership and Organizational Studies, 9, 57-64.

Seo, J., Nahrgang, J. D., Carter, M. Z., \& Hom, P. W. (2018). Not all differentiation is the same: Examining the moderating effects of leader-member exchange (LMX) configurations. Journal of Applied Psychology, 103, 478-495.

Smith, C. A., Organ, D. W., \& Near, J. P. (1983). Organizational citizenship behavior: Its nature and antecedents. Journal of Applied Psychology, 68, 653-663.

Stodgill, R. M. (1948). Personal factors associated with leadership: A survey of the literature. Journal of Psychology, 25, 35-71.

Stogdill, R. M. (1950). Leadership, membership and organization. Psychological Bulletin, 47, 1-14. 
Stone, A. G., Russell, R. F., \& Patterson, K. (2004). Transformational versus servant leadership: A difference in leader focus. The Leadership \& Organization Development Journal, 25, 349-361.

Tan, C., Krishnan, S., \& Lee, Q. (2017). The role of self-esteem and social support in the relationship between extraversion and happiness: A serial mediation model. Current Psychology: A Journal for Diverse Perspectives on Diverse Psychological Issues, 36, 556-564.

Van Dierendonck, D. (2011). Servant leadership: A review and synthesis. Journal of Management, 37, 1228-1261.

Walumbwa, F. O., Hartnell, C. A., \& Oke, A. (2010) Servant leadership, procedural justice climate, service climate, employee attitudes, and organizational citizenship behavior: A cross-level investigation. Journal of Applied Psychology, 95, 517-529.

Wang, Q., Bowling, N. A. (2016). A comparison of general and work-specific personality measures as predictors of organizational citizenship behavior. International Journal of Selection and Assessment, 24, 172-188.

Wayne, S. J., Shore, L. M., \& Liden, R. C. (1997). Perceived organizational support and leader-member exchange: A social exchange perspective. Academy of Management Journal, 40, 82-111.

Wong, P. T., Davey, D., \& Church, F. B. (2007). Best practices in servant leadership. Proceedings of the Servant Leadership Research Roundtable, Regent University,

Yammarino, F. (2013). Leadership: Past, present, and future. Journal of Leadership and Organizational Studies, 20, 149-155.

Yang, J., Liu, H., \& Gu, G. (2017). A multi-level study of servant leadership on creativity: The roles of self-efficacy and power distance. Leadership \& Organizational Development Journal, 38, 610-629.

Yang, R., Ming, Y., Ma, J., \& Huo, R. (2017). How do servant leaders promote engagement? A bottom-up perspective of job crafting. Social Behavior \& Personality: An International Journal, 45, 1815-1827.

Yukl, G. (2006). Leadership in organizations (6th ed.). Upper Saddle River, NJ: Pearson Education. 


\section{Appendix}

\section{Demographic Questionnaire}

Please indicate your current age.

- Younger than 18

○ $18-24$

○ 25-34

○ $35-44$

○ 45-54

○ $55-64$

○ $65^{*}$

What best describes the type of organization you work for?

- I am currently unemployed

- For profit

- Non-profit (religious, arts, social assistance, etc.)

o Government

- Health care

- Education

O Other

What is your employment status?
○ Part-time
○ Full-time

Please select the length of time you have been employed at your current company.
$\circ \quad$ Less than 6 months
- 6-12 months
○ 1-3 years
○ 4-6 years
○ 7+ years 
Please specify your ethnicity.

- Asian

- American Indian or Alaska Native

- Black or African American

- Hispanic, Latino, or Spanish origin

- Native Hawaiian / Pacific Islander

- White

O Other

- Prefer not to say

Please select your gender.

○ Male

- Female

o Non-binary

○ Transgender

o Other

- Prefer not to say 


\section{Scale Items}

\section{Servant Leadership Scale Items}

My supervisor spends time forming quality relationships with employees.

My supervisor creates a sense of community among employees.

My supervisor's decisions are influenced by employee's input.

My manager tries to reach consensus among employees on important decisions.

My supervisor is sensitive to employee's responsibilities outside the work place.

My supervisor makes the personal development of employees a priority.

My supervisor holds employees to high ethical standards.

My supervisor does what she or he promises to do.

My supervisor balances concern for day-to-day details with projections for the future.

My supervisor displays interest in finding solutions to work problems.

My supervisor makes me feel like I work with him/her, not for him/her.

My supervisor works hard at finding ways to help others be the best they can be.

My supervisor encourages employees to be involved in community service and volunteer activities outside of work.

My supervisor emphasizes the importance of giving back to the community.

\section{OCB Scale Items}

I help others who have been absent from work.

I willingly give my time to help others who have work-related problems.

I adjust my work schedule to accommodate other employees' requests for time off. I go out of the way to make newer employees feel welcome. 
I show genuine concern and courtesy toward coworkers, even under the most trying situations.

I give up time to help others who have work or non-work related problems.

I assist others with their duties.

I share personal property with others to help their work.

I attend company functions that are not required but that help the organizational image.

I keep up with developments in the organization.

I defend the organization when other employees criticize it.

I show pride when representing the organization in public.

I offer ideas to improve the functioning of the organization.

I express loyalty toward the organization.

I take action to protect the organization from potential problems.

I demonstrate concern about the image of the organization.

\section{Self-Esteem Scale Items}

On the whole, I am satisfied with myself.

At times I think I am no good at all.

I feel that I have a number of good qualities.

I am able to do things as well as most other people.

I feel I do not have much to be proud of.

I certainly feel useless at times.

I feel that I'm a person of worth, at least on an equal plane with others.

I wish I could have more respect for myself. 
All in all, I am inclined to feel that I am a failure.

I take a positive attitude toward myself. 